chenym vmistom pektynu. No. u201902416; declareted: 12.03.2019; published: 25.09.2019, Bul. No. 18. Available at: https://base.uipv.org/searchINV/search.php?action=viewdetails\&IdClaim=261919

[20] TU U 10.8-2860707498-001:2019. Vyrobnytstvo napivfabrykatu na osnovi zghushchenoi nyzkolaktoznoi molochnoi syrovatky ta dysperhovanoho piure z miakoti harbuza z pidvyshchenym vmistom pektynu. DKPP 10.84.12-70.

[21] Hnitsevych, V. A., Honchar, Yu. M. (2018). Pat. No. 129641 UA. Sposib vyrobnytstva fermentovanoi molochnoi syrovatky zi znyzhenym vmistom laktozy. No. u201803960; declareted: 12.04.2018; published: 12.11.2018, Bul. No. 21. Available at: https://base.uipv.org/searchINV/search.php?action=viewdetails\&IdClaim=252564

[22] Hnitsevych, V. A., Honchar, Yu. M. (2018). Pat. No. 129640 UA. Sposib vyrobnytstva fermentovanoho piure z miakoti harbuza z pidvyshchenym vmistom pektynu. No. u201803959; declareted: 12.04.2018; published: 12.11.2018, Bul. No. 21. Available at: https://base.uipv.org/searchINV/search.php?action=viewdetails\&dbname=inv\&lang=ukr\&chapter=biblio\&sortby=

[23] Gavrilova, N. N., Nazarov, V. V., Yarovaya, O. V. (2012). Mikroskopicheskie metody opredeleniya razmerov chastits dispersnyh materialov. Moscow: RHTU im. D. I. Mendeleeva, 52.

\title{
INFLUENCE OF ACTIVATED CARBON ON PHYSICAL AND CHEMICAL INDICATORS OF CHEDDAR CHEESE
}

\author{
Marina Samilyk \\ m.samilyk@ukr.net \\ Anna Helikh ${ }^{1}$ \\ gelihsumy@gmail.com \\ Natalia Bolgova ${ }^{1}$ \\ bolgova_1981@i.ua \\ Iryna Yaremenko \\ yaremenko713@gmail.com \\ ${ }^{1}$ Sumy National Agrarian University \\ 160 Gerasim Kondratyev str., Sumy, Ukraine, 40000
}

\footnotetext{
Abstract

The aim of this research is to substantiate the possibility of using crushed activated carbon (hereinafter referred to as activated carbon) as a food additive in the production of Cheddar cheese in order to expand the range of this type of cheese on the market.

The studied samples of Cheddar cheese, produced in accordance with the technological instructions approved in the prescribed manner, in compliance with the state sanitary regulations for dairy enterprises in accordance with GSP 4.4.4.011.

According to the research results, all physicochemical, microbiological and toxicological indicators comply with the requirements of DSTU 6003:2008.

It is proved that the introduction of activated carbon helps to reduce the amount of moisture without increasing the level of acidity in the finished product. Thus, ensuring the compliance of physico-chemical and microbiological indicators with the requirements of the standard.

In the process of laboratory studies, the presence of carbohydrates in the control and experimental samples is revealed, which indicates the incomplete ripening of cheese in the process of cheddarization. It is established that the introduction of activated carbon during the ripening of cheese helps to reduce the amount of carbohydrates by $2.8 \%$.

The introduction of activated carbon helps to reduce the moisture content by $0.4 \%$, in comparison with the sample without its use. The influence of activated carbon on the indicators of active and triturated acidity, which affect the safety indicators of
} 
cheddar cheese during storage for 30 days, is analyzed. As a result of the study, lower pH values of a sample of cheddar cheese with activated carbon are obtained, which helps to suppress the growth of conditionally pathogenic microflora of cheese and stabilizes microbiological parameters during storage of Cheddar cheese with activated carbon.

It is proved that cheddar cheese with activated carbon maintains high quality indicators throughout the entire storage period.

Keywords: microbiological indicators, toxicological indicators, Cheddar cheese, activated carbon, moisture content, acidity.

DOI: $10.21303 / 2504-5695.2020 .001327$

\section{Introduction}

Cheddar refers to cheeses with a low second heating temperature $\left(32-37^{\circ} \mathrm{C}\right)$ with a high level of lactic acid fermentation, which contributes to the rapid reproduction of both lactic acid bacteria and undesirable pathogenic microflora $[1,2]$.

Cheeses are a source of protein (up to $25 \%$ ), milk fat (up to $60 \%$ ) and minerals (up to $3.5 \%$, not including salt). Cheese proteins are better absorbed by the body than milk proteins. Extractive substances of cheese have a beneficial effect on the digestive glands, stimulate appetite. The nutrients contained in cheese are absorbed by the body almost completely (98-99\%). Cheeses contain vitamins A, D, E, B1, B2, B12, PP, C, pantothenic acid and others. The content of calcium and phosphorus are in the cheddar in an optimally balanced ratio [3].

Cheddar cheese can be used as a ready-to-eat product, as well as a raw material in the manufacture of a variety of products. Most often, spices and vegetable fillers are used in the production of cheddar cheese as additives that add certain taste qualities [4].

In terms of chemical composition, cheddar is a good environment for the nutrition and respiration of microorganisms. The presence of a large amount of protein in it has a protective effect on microorganisms - the protein adsorbs and neutralizes the accumulating lactic acid. But the action of the protein is quite short-lived [5].

During cheddar production, the temperature of the second heating is low and amounts to $32-37^{\circ} \mathrm{C}$, which contributes to the rapid reproduction of lactic acid bacteria, including pathogenic microflora. The content of lactic acid sticks in fresh cheese is insignificant; by the end of ripening, their number exceeds the number of streptococci. In mature cheese, mesophilic lactobacilli and lactic streptococci predominate $[1,2]$. The increase in microflora and humidity is facilitated by cheddarization - holding the formation in a cheese bath for several hours until the required acidity increases. The increase in acidity and moisture during cheddarization of cheese mass is a problem in the technology of cheddar cheese. Therefore, the search for ways to maximize its stabilization is relevant.

The use of crushed activated carbon in cheddar cheese technology is currently very relevant. Activated carbon in cheddar cheese technology allows to control the amount of carbohydrates and moisture. Having high sorption properties, coal partially absorbs moisture from cheese grain, as well as toxic elements, radionuclides, etc. Thus, preventing the active development of pathogenic microflora and ensures the environmental friendliness of the product [6].

The study [7] describes the quality of cheeses using spinach nanopowder $(0.5 \%, 1.0 \%$, $1.5 \%$ and $2 \%$ ), namely, chemical composition, color, sensory and antioxidant properties. However, this study does not say anything about the safety and storage lines of this cheese.

The work [8] evaluates the microbiological safety associated with pathogens Listeria monocytogenes, Staphylococcus aureus and Escherichia coli, causing infectious food diseases associated with the use of cheese. As part of the microbiological safety assessment, prognostic models have been developed to describe the relationship between several factors ( $\mathrm{pH}$ and starting culture). However, for an accurate quantitative assessment of microbiological stability, more data must be provided, including factors such as cheese preparation conditions (temperature and time) and ripening period.

The work [9] presents studies of the microbiological quality of young cheese, a variety of traditional cheese, which is mainly made from sheep's milk. However, the aim of research is determination of the quality of milk pasteurization on the indicators of microbiological stability of 
cheese. But the indicators of microflora, including pathogenic, during the ripening of cheese are not given.

Microbiology and changes in the basic physicochemical parameters, as well as the development of protein proteolysis and lipolysis of fat fractions of traditional Greek cheese, are studied [10]. However, in this study, toxicological indicators are not indicated and not justified.

In the study [11], various antibacterial solutions are tested as additives to traditional raw milk cheeses, including Nigella sativa cold-pressed oil (NSSO). QMAFAnM content showed similar values for control cheeses and NSSO cheeses, and no significant differences are observed in the three treatment groups during maturation. The overall effect on the quality of fortified cheeses during ripening is still being studied.

A study [12] is conducted to assess the antioxidant potential of young cheese - paneer, enriched with various water-soluble extracts of dates during storage. It has been established that date extracts have significant antioxidant activity due to the presence of common phenolic and flavonoid preparations. Due to the presence of phenolic and flavonoids in date extracts, cheese has shown higher antioxidant ability.

The work [13] presents the results of a study of changes in the physicochemical and microbiological properties of Turkish hard cheeses during a 90-day ripening period. Physico-chemical characteristics are the same for all cheese samples. Microbiological indicators are normal throughout the ripening period.

In [14], the PetrifilmTM Aerobic Counting Plate (ACP), developed by 3M Laboratories, is a ready-to-use nutrient medium system useful for counting aerobic bacteria in foods. PetrifilmTM is compared with the standard method in several different foods with satisfactory results. However, many studies have shown that the number of bacteria in PetrifilmTM is significantly lower than the amount obtained by conventional methods in fermented foods.

In [15], 108 samples of young cheeses produced in the markets of Pancevo, Subotica and Belgrade are investigated. Microbiological analysis of cheese samples for the presence of Escherichia coli is carried out using the methods described in the Regulation on the methods of microbiological analysis and superanalysis of consumer goods in the presence of Enteroccocus spp bacteria is performed on Dexter agar. Of 108 soft cheese samples from the territories of Pancevo, Belgrade and Subotica, the following are isolated: Enterococcus spp. from $96 \%$ and Escherichia coli from $69 \%$, cheese samples. Verocytotoxic E. coli is not isolated from any of the cheese samples taken.

A comprehensive study [16] is conducted on the addition of flour from milk thistle seeds to cheese in an amount of 1.0-2.5\%. Flour from milk thistle seeds, which is a source of flavolignans, helps to increase the nutritional value of cheese with an increase in protein content by $0.11-0.24 \%$, fat by $0.06-0.12 \%$, and carbohydrates by $0.13-0.28 \%$ and silymarin - up to $3.39-7.26 \mathrm{mg} / 100 \mathrm{~g}$ of product and extension of storage period up to 8 days. Acidity and microbiological indicators correspond to the established level. However, the additive affects the taste of the product, giving it a muddy flavor.

An analysis of the literature shows that the issue of stabilizing moisture and acidity during storage of cheddar cheese remained unresolved, which allows the microbiological and toxicological parameters of cheddar cheese to be maximally preserved during ripening and storage. And also, methods for reducing the amount of carbohydrates in cheese, which are a source of gas formation, are not presented. In our research, a way to solve this problem is proposed.

The aim of this research is to justify the use of crushed activated carbon to improve the quality indicators of cheddar cheese. And the effect of activated carbon on physico-chemical parameters, acidity, microbiological and toxicological parameters during storage.

To achieve the aim, the following objectives are set:

- determine the effect of added activated carbon on the physico-chemical characteristics of cheddar cheese;

- determine the effect of added activated carbon on acidity during storage of cheddar cheese; 
- determine the effect of activated carbon on the microbiological and toxicological parameters of cheddar cheese during storage;

- analyze the effect of activated carbon on the quality of cheddar cheese during storage.

The analysis of the use of various additives to cheese is carried out. Thus, let's look at why to conduct this or that analysis with our cheese with the addition of activated carbon and what it gives in the end.

\section{Materials and methods}

The objects of research are cheddar cheese samples obtained according to the standard recipe, and cheddar cheese samples enriched with activated carbon. Activated carbon (PJSC SIC "Borshchahivskiy CPP") used in the manufacture of the experimental sample, in terms of safety, meets the requirements established by the MBR No. 5061

Both samples are produced using Streptococcus thermophilus monocultures and mixed cultures of L. lactis ssp. lactis + L. lactis ssp. cremoris company "CHR. Hansen” (Denmark)

Samples of cheddar cheese with activated carbon are made in the laboratory of the Department of Milk and Meat Technology of Sumy National Agrarian University. A sample of cheddar cheese and activated carbon cheddar cheese is shown in Fig. 1, 2.

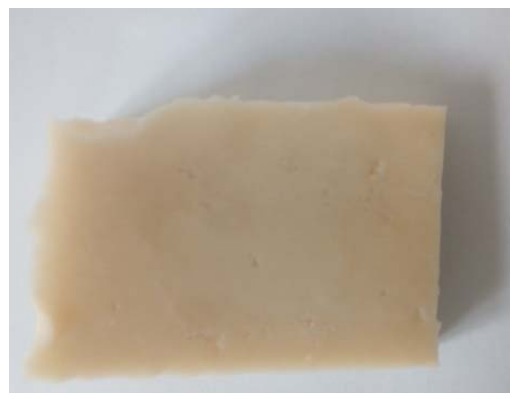

Fig. 1. Cheddar cheese

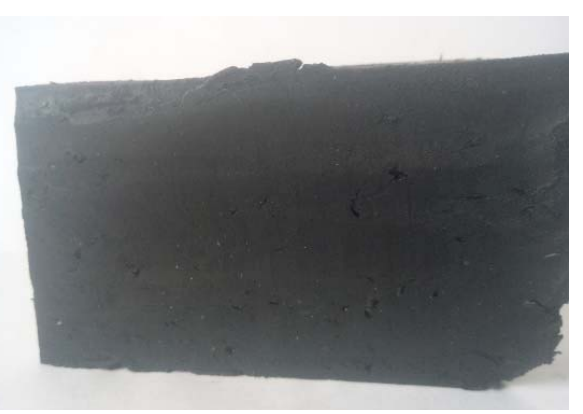

Fig. 2. Cheddar cheese with activated carbon

The studied samples were stored in a domestic refrigerator in the form of cheese heads without vacuum at a temperature of $2-4{ }^{\circ} \mathrm{C}$. Storage lines was 30 days. The studies were carried out at the beginning of storage on the 1st day, after 7, 14 and 30 days.

When performing the study, titratable acidity of control samples and test samples of cheddar cheese with activated carbon was determined by the titrometric method according to GOST 3624-92.

Active acidity was determined by potentiometric method according to GOST 25754-85.

The mass moisture content $(X)$ in percent was determined according to DSTU 8552:2015, and was calculated by the formula:

$$
X=\frac{m_{1}-m_{2}}{m_{1}-m_{3}} \cdot K \cdot 100,
$$


where $m_{1}$ - the mass of the weighing cup with a lid, a stick, sand and a hitch before drying, $g ; m_{2}-$ the mass of the weighing cup with a lid, a stick, sand and a hitch after drying, $\mathrm{g} ; m_{3}-$ the mass of the weighing cup with a lid, a stick, sand, g; $K$ - correction factor.

The carbohydrate content in cheese was determined by the polarimetric method (GOST 3628-78). The method is based on the destruction of lactose by calcium oxide and the polarimetric determination of sucrose. The method is based on the property of asymmetric carbohydrate carbon atoms to rotate the plane of polarization of a polarized beam and reduces to determining the angle of rotation of polarized light. As a polarizer, they use the Nicol prism, which is cut from an Icelandic spar in the shape of a parallelepiped, cut diagonally and glued together with a Canadian balsam. It has the ability to polarize light.

The number of bacteria of the Escherichia coli group (coliform bacteria) was according to GOST 9225. The number of bacteria of the Salmonella group was according to DSTU IDF 93A. The number of bacteria of the Listeria monocytogenes group is according to DSTU ISO 11290-1, DSTU ISO 11290-2. The number of bacteria of the group Staphylococcus aureus was determined in accordance with GOST 30347.

The content of toxic elements was determined according to GOST 30178 or lead according to GOST 26932, cadmium according to GOST 26933, arsenic according to GOST 26930, mercury according to GOST 26927, sample preparation according to GOST 26929.11.14.

\section{Results}

All experimental samples of cheddar cheese for 30 days of storage, not ripening, were characterized by a clean sour-milk taste, without extraneous smacks and smells, a homogeneous, undisturbed consistency, and a color that was uniform throughout the mass of the product. The color for the control sample was light yellow, for the experimental with activated carbon - marble black.

At the first stage of the study, physicochemical parameters (mass moisture content, mass content of carbohydrates) and titratable and active acidity indices of the control and experimental samples of cheddar cheese with activated carbon during storage were determined (Table 1).

Table 1

Physico-chemical characteristics of the experimental and control samples of cheddar cheese

\begin{tabular}{cccc}
\hline Name of indicator & Control & Experiment & DSTU norm \\
\hline $\begin{array}{c}\text { Mass moisture content, } \% \\
\text { Mass content of carbohydrates, } \% \\
\quad \text { is not standardized }\end{array}$ & 37,9 & 37,5 & 47 \\
\end{tabular}

The mass moisture content in the control sample is $0.4 \%$ higher than in the experimental one. The decrease in moisture content in the activated carbon sample occurs due to adsorption.

The carbohydrate content in the control sample is $2.8 \%$ higher than the mass content of carbohydrates in the experimental activated carbon. According to the acts of the experiments, the free aldehyde group of glucose and the ketone group of galactose interact with activated carbon and act as reducing agents (reducing sugars) in a redox reaction. Thus, the amount of monosaccharides in cheese is reduced by almost 2 times, as evidenced by the data obtained.

The titrated acidity of the experimental and control samples of cheddar cheese during storage increases and is: at the beginning of storage - 188-151, after 7 days - 201-159, after 14 days $-219-163{ }^{\circ} \mathrm{T}$, after 30 days $-226-169^{\circ} \mathrm{T}$ (Fig. 3). Over the entire storage period, the acidity of the control sample increases by $38^{\circ} \mathrm{T}$, and the acidity of the activated carbon sample increases by only $18^{\circ} \mathrm{T}$. 
The active acidity of the experimental and control samples of cheddar cheese during storage is reduced and is: at the beginning of storage - 5.09-5.2, after 7 days - 5.07-5.15, after 14 days 5.01-5.1 pH, after 30 days 5.0-5.05 pH (Fig. 4).

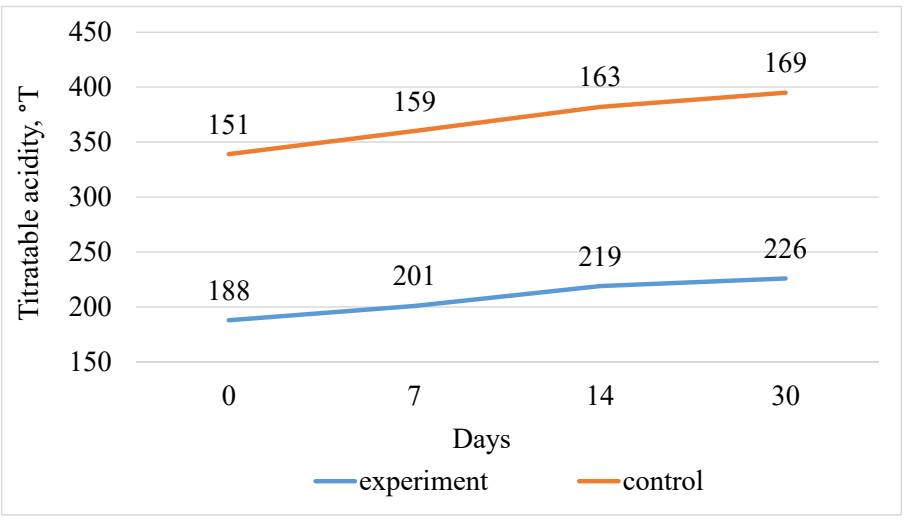

Fig. 3. Titratable acidity

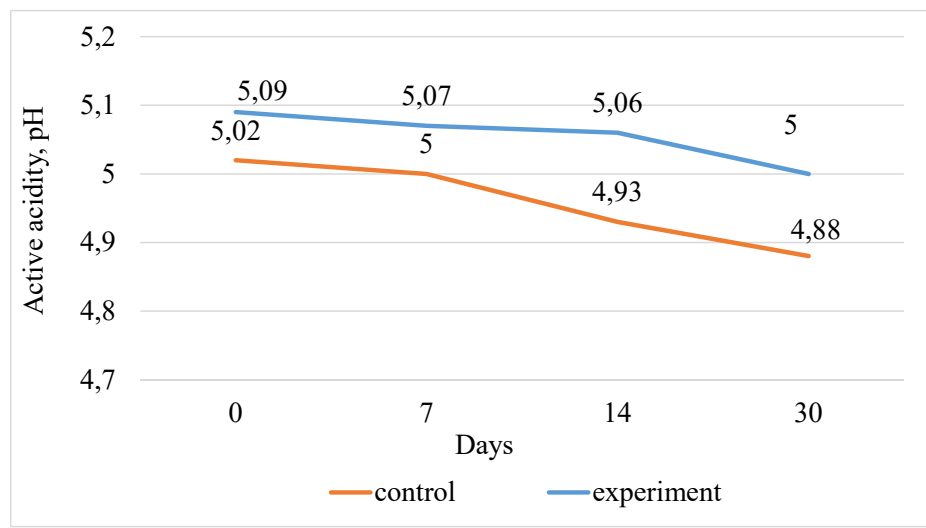

Fig. 4. Active acidity

The highest titratable acidity during the entire storage process - (151-173) ${ }^{\circ} \mathrm{T}$ - was observed in the experimental sample of cheddar cheese at the beginning of storage and after 30 days of storage, which includes activated carbon. The same sample has the highest active acidity of the cheese mass after 30 days of storage days of storage $-5.05 \mathrm{pH}$. This is because activated carbon introduced into the cheese mass does not adsorb lactic and acetic acid, which is a stronger electrolyte, during the fermentation of sugars.

The second stage of the study was the determination of the change in the number of bacteria of the Escherichia coli group (coliform bacteria) in $0.01 \mathrm{~g}$ of cheese, bacteria of the Salmonella group, bacteria of the Listeria monocytogenes group and Staphylococcus aureus in the experimental and control cheese samples during storage (Table 2).

Data are provided to compare Cheddar cheese with activated carbon and classic. So let's show that our sample is also safe.

A study of the microbiological parameters of a control sample of cheddar cheese and an experimental sample with activated carbon during storage (30 days) indicates that the conditionally pathogenic and pathogenic microflora is within acceptable values. Determination of coliforms in $0.01 \mathrm{~g}$ of experimental and control samples of cheddar cheese indicate their absence in the test mass of the product. However, there are quantitative differences in the growth indicators of Staphylococcus aureus during storage. The number of bacteria of the group Staphylococcus aureus in the experimental and control samples during the first 7 days of storage is the same and is $4.4 \times 10^{2}$. But starting from the 14 th day of storage of samples, bifidobacteria gradually die. 
Given the unfavorable environmental situation, the study of safety indicators, which are characterized by the presence of toxic elements in food products, deserves considerable attention (Table 3).

Table 2

Change in microbiological parameters in the experimental and control samples of cheddar cheese during storage

\begin{tabular}{|c|c|c|c|c|c|c|}
\hline \multirow{2}{*}{ Indicator name } & \multirow{2}{*}{ Allowable level } & \multirow{2}{*}{ Sample } & \multicolumn{4}{|c|}{ Storage period, days } \\
\hline & & & $\mathbf{0}$ & 7 & 14 & 30 \\
\hline \multirow[t]{2}{*}{$\begin{array}{c}\text { Coliform bacteria (coliforms), in } 0.01 \mathrm{~g} \text { of } \\
\text { cheese }\end{array}$} & $\begin{array}{l}\text { Not allowed according to } \\
\text { DSTU 6003:2008 }\end{array}$ & Control & - & - & - & - \\
\hline & & Experiment & - & - & - & - \\
\hline \multirow{2}{*}{$\begin{array}{c}\text { Pathogenic microorganisms, including } \\
\text { bacteria of the genus Salmonella, in } 25 \mathrm{~g} \text { of } \\
\text { cheese }\end{array}$} & \multirow[t]{2}{*}{ Not allowed } & Control & - & - & - & - \\
\hline & & Experiment & - & - & - & - \\
\hline \multirow{2}{*}{$\begin{array}{c}\text { Staphylococcus aureus, in } 1 \mathrm{~g} \text { of cheese, not } \\
\text { more than }\end{array}$} & \multirow{2}{*}{$5.0 \times 10^{2}$} & Control & $4.4 \times 10^{2}$ & $4.4 \times 10^{2}$ & $4.8 \times 10^{2}$ & $4.9 \times 10^{2}$ \\
\hline & & Experiment & $4.4 \times 10^{2}$ & $4.4 \times 10^{2}$ & $4.4 \times 10^{2}$ & $4.4 \times 10^{2}$ \\
\hline \multirow{2}{*}{ Listeria monocytogenes, in $25 \mathrm{~g}$ of cheese } & \multirow{2}{*}{ Not allowed } & Control & - & - & - & - \\
\hline & & Experiment & - & - & - & - \\
\hline
\end{tabular}

Table 3

Toxicological parameters in the experimental and control samples of cheddar cheese during storage

\begin{tabular}{|c|c|c|c|c|c|c|}
\hline \multirow{2}{*}{ Indicator name $\mathbf{r}$} & \multirow{2}{*}{ Allowable level, no more } & \multirow{2}{*}{ Sample } & \multicolumn{4}{|c|}{ Storage period, days } \\
\hline & & & $\mathbf{0}$ & 7 & 14 & 30 \\
\hline \multirow{2}{*}{ Plumbum } & \multirow{2}{*}{0,3} & Control & 0,1 & 0,1 & 0,1 & 0,1 \\
\hline & & Experiment & 0,1 & 0,1 & 0,1 & 0,1 \\
\hline \multirow{2}{*}{ Cadmium } & \multirow{2}{*}{0,2} & Control & 0,14 & 0,14 & 0,14 & 0,14 \\
\hline & & Experiment & 0,14 & 0,14 & 0,14 & 0,14 \\
\hline \multirow{2}{*}{ Arsenic } & \multirow{2}{*}{0,2} & Control & 0,01 & 0,01 & 0,01 & 0,01 \\
\hline & & Experiment & 0,01 & 0,01 & 0,01 & 0,01 \\
\hline \multirow{2}{*}{ Mercury } & \multirow{2}{*}{0,02} & Control & - & - & - & - \\
\hline & & Experiment & - & - & - & - \\
\hline
\end{tabular}

It can be noted that for all types of toxicological indicators, the control and experimental samples of cheddar cheese with activated carbon satisfy the toxicological requirements for this type of product according to DSTU 6003:2008 [17].

\section{Conclusions}

The effect of added activated carbon on the physicochemical characteristics of cheddar cheese is determined. The mass moisture content in the control sample is $0.4 \%$ higher than in the experimental one. The mass content of carbohydrates in the control sample is two times higher than in the experimental activated carbon. Such low carbohydrate content in the experimental sample is explained by the fact that the enzyme $\beta$-galactosidase breaks down lactose disaccharide into glucose and galactose. The free aldehyde group of glucose and the ketone group of galactose interact with activated carbon and act as reducing agents (reducing sugars) 
in a redox reaction. Thus, the amount of monosaccharides in cheese is reduced, as evidenced by the data obtained.

The effect of added activated carbon on acidity during storage of cheddar cheese was determined. It is proved that the titratable acidity of the experimental and control samples of cheddar cheese during storage increases and by the end of storage on the 30th day it increases by $18^{\circ} \mathrm{T}$ for the experimental sample, and by $38^{\circ} \mathrm{T}$ for the control. The active acidity of the experimental and control samples of cheddar cheese during storage decreases by the end of storage on the 30th day by 0.9 for the experimental sample and 3.2 - for the control sample. Lower $\mathrm{pH}$ values in the cheese sample with activated carbon help to suppress the growth of conditionally pathogenic microflora of cheese and stabilize microbiological parameters during storage.

The effect of activated carbon on the microbiological and toxicological parameters of cheddar cheese during storage is determined. A study of the microbiological parameters of a control sample of cheddar cheese and an experimental sample with activated carbon during storage (30 days) indicates that the conditionally pathogenic and pathogenic microflora is within acceptable values. The number of bacteria of the group Staphylococcus aureus in the experimental and control samples during the first 7 days of storage is the same and is $4.4 \times 10^{2}$. But starting from the 14th day of storage of samples, bifidobacteria gradually die. This is due to higher $\mathrm{pH}$ values in the control cheese samples. Due to which there is an active accumulation of bacteria of the group Staphylococcus aureus up to $4.9 \times 10^{2}$ on the 30 th day of storage. Toxicological studies have shown that cheddar cheese samples with activated carbon have been developed for safety indicators that meet the toxicological requirements for this type of product according to DSTU 6003: 2008 [17].

Based on the studies, it is proved that cheddar cheese with activated carbon retains high quality indicators throughout the entire storage period.

\section{References}

[1] Claps, S., Pizzillo, M., Agoglia, E., Schettino, M. V., Sabia, E., Rubino, R. (2007). Chemical and texture characteristics and sensory properties of "mozzarella" cheese from different feeding systems. Italian Journal of Animal Science, 6 (sup2), $1143-$ 1146. doi: https://doi.org/10.4081/ijas.2007.s2.1143

[2] Filho, A. D. S. S., Pires, C. V., Cardoso, W. J., Pinto, M. S., Oliveira, N. J. F. de. (2016). Physical characterization and sanitary conditions of cheese type cabacinha market places in three municipalities of the Jequitinhonha Valley, MG, Brazil. Revista Do Instituto de Laticínios Cândido Tostes, 71 (4). doi: https://doi.org/10.14295/2238-6416.v71i4.511

[3] Marín, P., Ginés, C., Kochaki, P., Jurado, M. (2017). Effects of water activity on the performance of potassium sorbate and natamycin as preservatives against cheese spoilage moulds. Irish Journal of Agricultural and Food Research, 56 (1), 85-92. doi: https://doi.org/10.1515/ijafr-2017-0009

[4] Rudavska, A. B., Deinychenko, H. V., Kozlov, V. M., Diukareva, H. I. (2004). Tovaroznavstvo molochnykh tovariv. Kyiv: Profesional, 312.

[5] Qureshi, T. M., Amjad, A., Nadeem, M., Murtaza, M. A., Munir, M. (2019). Antioxidant potential of a soft cheese (paneer) supplemented with the extracts of date (Phoenix dactylifera L.) cultivars and its whey. Asian-Australasian Journal of Animal Sciences, 32 (10), 1591-1602. doi: https://doi.org/10.5713/ajas.18.0750

[6] Weller, R., Minikin, A., Petzold, A., Wagenbach, D., König-Langlo, G. (2013). Characterization of long-term and seasonal variations of black carbon (BC) concentrations at Neumayer, Antarctica. Atmospheric Chemistry and Physics, 13 (3), 1579 1590. doi: https://doi.org/10.5194/acp-13-1579-2013

[7] El-Sayed, S. M. (2020). Use of spinach powder as functional ingredient in the manufacture of UF-Soft cheese. Heliyon, 6 (1), e03278. doi: https://doi.org/10.1016/j.heliyon.2020.e03278

[8] Choi, K.-H., Lee, H., Lee, S., Kim, S., Yoon, Y. (2016). Cheese Microbial Risk Assessments - A Review. Asian-Australasian Journal of Animal Sciences, 29 (3), 307-314. doi: https://doi.org/10.5713/ajas.15.0332

[9] AL-Hamdany, M. H. A., Hassan, A. A. (2017). Microbiological quality of white local sheep cheese in Mosul city markets. Iraqi Journal of Veterinary Sciences, 31 (1), 1-6. doi: https://doi.org/10.33899/ijvs.2017.126712

[10] Pappa, E. C., Bontinis, T. G., Tasioula-Margari, M., Samelis, J. (2017). Microbial Quality of and Biochemical Changes in Fresh Soft, Acid-Curd Xinotyri Cheese Made from Raw or Pasteurized Goat's Milk. Food Technology and Biotechnology, 55 (4), 496-510. doi: https://doi.org/10.17113/ftb.55.04.17.5338 
[11] Georgescu, M., Raita, Ștefania M., Tăpăloagă, D. (2019). Total nitrogen, water-soluble nitrogen and free amino acids profile during ripening of soft cheese enriched with Nigella sativa seed oil. The EuroBiotech Journal, 3 (2), 90-96. doi: https:// doi.org/10.2478/ebtj-2019-0010

[12] Qureshi, T. M., Amjad, A., Nadeem, M., Murtaza, M. A., Munir, M. (2019). Antioxidant potential of a soft cheese (paneer) supplemented with the extracts of date (Phoenix dactylifera L.) cultivars and its whey. Asian-Australasian Journal of Animal Sciences, 32 (10), 1591-1602. doi: https://doi.org/10.5713/ajas.18.0750

[13] Ozcan, T., Eren-Vapur, U. (2013). Effect of Different Rennet Type on Physico-Chemical Properties and Bitterness in White Cheese. International Journal of Environmental Science and Development, 4 (1), 71-75. doi: https://doi.org/10.7763/ijesd.2013. v4.307

[14] De Sousa, G. B., Tamagnini, L. M., González, R. D., Budde, C. E. (2005). Evaluation of Petrifilm method for enumerating aerobic bacteria in Crottin goat cheese. Revista Argentina de Microbiología, 37 (4), 214-216.

[15] Tambur, Z., Opacic, D., Doder, R., Markovic, M. (2007). Findings of Escherichia coli and Enterococcus spp. in homemade cheese. Veterinarski Glasnik, 61 (1-2), 109-113. doi: https://doi.org/10.2298/vetg10702109t

[16] Timakova, R. T. (2019). Formation of consumer value of cottage cheese prolonged shelf life when using flour from milk Thistle seeds spotted. Proceedings of the Voronezh State University of Engineering Technologies, 81 (3), 43-49. doi: https:// doi.org/10.20914/2310-1202-2019-3-43-49

[17] DSTU 6003:2008. Cheese Hard. General Specification (2009). Kyiv. 